\title{
Sanukitoids and the origin of secondary I-type granites
}

\author{
ANTONIO CASTRO ${ }^{1}$, DANIEL GÓMEZ-FRUTOS ${ }^{2}$ \\ ${ }^{1}$ Institute of Geosciences (IGEO), CSIC-UCM, Ciudad \\ Universitaria, Madrid, Spain \\ ${ }^{2}$ Departamento de Mineralogía y Petrología. Universidad \\ Complutense de Madrid, Ciudad Universitaria, Madrid, \\ Spain.
}

I-type granites are by far the most abundant in the crust. They form both the large Andean-type batholiths at active continental margins and the post-collisional batholiths that mostly characterize ancient orogenic belts. Melting of an infracrustal source, as it was postulated in the ChappellWhite's classification of granites, can be accomplished in two ways giving rise to primary an secondary magmas. Primary granites are formed by fractionation of intermediate (dioritic) magmas that arrive to the crust from the underlying mantle. Secondary granites are formed by melting of an older igneous source residing in the crust. Melting of lower crust cumulates (granulites) from primary granite segregation may produce new granite melts (secondary) if conditions of melting with addition of water are satisfied. The arrival to the lower crust of wet mafic magmas (sanukitoids) may trigger melting of crustal granulites to produce new granitic magmas. We show here laboratory experiments on water-assisted melting of granulites that support this secondary origin for many I-type batholiths. Hydrous monzodiorites, or sanukitoids, are commonly found in association with granite batholiths in post-collisional orogens. The water content of these intermediate magmas is determined by means of crystallization experiments and trace element partitioning between solid phases and the co-existing hydrous liquid. 